\title{
Pemanfaatan Kitosan untuk Menurunkan Kadar Logam Pb pada Perairan yang Tercemar Minyak Bumi
}

\author{
Rima Rosema*, Endang Supriyantini, Sri Sedjati \\ Departemen Ilmu Kelautan, FakultasPerikanan dan Ilmu Kelautan, Universitas Diponegoro \\ Jl. Prof. Soedarto,SH, Tembalang, Semarang, Jawa Tengah, 50275 \\ Email: rimarosemaa@gmail.com
}

\begin{abstract}
Abstrak
Kitosan telah banyak dimanfaatkan dalam berbagai bidang kehidupan manusia, salah satunya dijadikan sebagai adsorben logam berat. Logam berat timbal $(\mathrm{Pb})$ merupakan polutan yang mencemari perairan dan bersifat toksik. Penelitian ini bertujuan untuk menguji kapasitas dan daya adsorpsi larutan kitosan komersial dan non komersial (produk sendiri) dalam konsentrasi berbeda terhadap logam $\mathrm{Pb}$. Metode penelitian yang digunakan yaitu eksperimental laboratoris dengan rancangan percobaan Faktorial 2 Aras dengan menggunakan 1 kontrol (0\%) dan 4 perlakuan yaitu konsentrasi 0,5\% (A), 1\% (B), 1,5\% (C) dan 2\% (D). Hasil penelitian menunjukkan bahwa terdapat interaksi antara sumber kitosan dengan konsentrasi kitosan untuk menurunkan kandungan $\mathrm{Pb}$. Dosis terbaik yang mampu menurunkan logam $\mathrm{Pb}$ untuk kitosan komersial yaitu pada konsentrasi $1 \%$ dengan kapasitas penyerapan sebesar 0,228 mg/g dan kemampuan penyerapan sebesar $87,870 \%$. Sedangkan kitosan non komersial mampu menurunkan logam $\mathrm{Pb}$ pada konsentrasi 1,5\% dengan kapasitas penyerapan sebesar $0,143 \mathrm{mg} / \mathrm{g}$ dan kemampuan penyerapan sebesar $82,660 \%$.
\end{abstract}

Kata kunci : Kitosan, Logam Berat Timbal (Pb), Adsorpsi

\section{Abstract}

\section{Utilization of Chitosan to Reduce Pb Metal Content in Water Contaminated by Petroleum}

Chitosan has been widely used in various fields of human life, one of which is used as a heavy metal adsorbent. Lead heavy metals $(\mathrm{Pb})$ is a pollutants that pollutes the waters and is toxic. This study aims to examine the capacity and adsorption capacity of commercial and non-commercial chitosan solutions (own products) in different concentrations of $\mathrm{Pb}$ metal. The research method used is an experimental laboratories with chitosan from the isolation itself and commercial chitosan. The research method used is an experimental laboratory with 2 Aras factorial experimental design using 1 control $(0 \%)$ and 4 treatments namely a concentrations of $0.5 \%(A), 1 \%(B), 1.5 \%(C)$ and $2 \%(D)$. The results showed that there was an interaction between chitosan sources and chitosan concentration to reduce Pb content. The best dose that can reduce Pb metal for commercial chitosan is at a concentration of $1 \%$ with an adsorption capacity of $0.228 \mathrm{mg} / \mathrm{g}$, and an adsorption ability of $87.870 \%$. while non-commercial chitosan can reduce $\mathrm{Pb}$ metal at a concentration of $1.5 \%$ with an adsorption capacity of $0.143 \mathrm{mg} / \mathrm{g}$ and an adsorption ability of $82.660 \%$.

Keywords : Chitosan, Heavy Metal Lead (Pb), Adsorption

\section{PENDAHULUAN}

Pencemaran lingkungan perairan oleh logam berat seperti timbal $(\mathrm{Pb})$ pada umumnya terjadi akibat sumber pencemar dari buangan limbah industri, pertambangan, tumpahan minyak dan kilang minyak (Susanti dan Kristiani, 2016). Minyak bumi mengandung minyak mentah (crude oil) yang merupakan golongan senyawa yang memiliki bersifat B3 (Bahan Berbahaya dan Beracun) yang mengandung hidrokarbon antara 
lain benzena, toluena, ethylbenzena, xylena dan logam berat seperti timbal $(\mathrm{Pb})$ (Hananingtyas, 2017). $\mathrm{Pb}$ berbahaya bagi lingkungan karena sifatnya sangat beracun, mempunyai sifat bioakumulatif dalam tubuh biota jika keberadaannya melampaui ambang batas dan terkontaminasi dalam kurun waktu yang lama (Raja dan Nurfajriani, 2017). Daya toksik yang tinggi dari logam berat mendorong adanya suatu pemikiran untuk menyelesaikan permasalahan pencemaran logam berat secara ramah lingkungan dan tidak menimbulkan efek negatif kepada lingkungan. Zaini dan Sami (2017) menyampaikan metode baru yang murah, efektif, dan efisien yang dikembangkan untuk menurunkan kadar logam berat dalam air antara lain pengendapan kimia, filtrasi mekanik, penukar ion, elektrode posisi, oksidasi-reduksi, sistem membran, dan adsorpsi fisik.

Proses adsorpsi lebih banyak dipakai dalam industri karena lebih ekonomis dan tidak menimbulkan efek samping yang beracun, salah satunya adalah penggunaan adsorben yang mengandung polimer alam seperti kitosan. Kitosan merupakan biopolimer alami yang berasal dari cangkang hewan seperti udang, kepiting, rajungan, dan kerang, yang memiliki sifat non toksik (Utami et al., 2014). Kitosan memiliki gugus hidroksil dan amino sepanjang rantai polimernya, sehingga kitosan dapat sangat efektif mengadsorpsi kation ion logam berat maupun kation dari zat - zat organik yaitu lemak dan protein (Pratiwi, 2014). Kitosan memiliki karakteristik fisika kimia, stabilitas kimia, reaktivitas yang tinggi, sifat chelation yang tinggi, dan selektivitas yang tinggi terhadap polutan (Sukma et al. 2018). Kitosan dapat mengadsorpsi logam berat pencemar seperti timbal $(\mathrm{Pb})$ karena adanya gugus amina dan hidroksil yang mempunyai kemampuan berikatan kovalen koordinasi dengan ion-ion logam dan bersifat sebagai bahan pengkhelat (Susilowati et al., 2018). Penelitian ini bertujuan untuk menguji kapasitas adsorpsi dan daya adsorpsi larutan kitosan komersial dan produk sendiri dalam konsentrasi berbeda terhadap logam $\mathrm{Pb}$.

\section{MATERI DAN METODE}

Materi yang digunakan adalah air laut tercemar minyak bumi yang diambil dari Perairan Karawang Utara pada bulan September 2019. Menurut Hananingtyas (2017) minyak bumi mengandung logam pencemar seperti timbal, sehingga dijadikan sebagai sampel uji. Kitosan yang digunakan adalah kitosan hasil isolasi sendiri dengan menggunakan limbah cangkang rajungan dari Industri Pengolahan di Desa Betahwalang, Kabupaten Demak. dan kitosan komersial Produk Generik. Metode penelitian yang digunakan yaitu eksperimental laboratoris dengan rancangan percobaan Faktorial 2 Aras, dimana Aras pertama adalah Jenis Kitosan (non komersial dan komersial); dan Aras kedua adalah konsentrasi kitosan yang berbeda. Konsentrasi kitosan pada aras kedua adalah sampel air uji sebagai kontrol tanpa pemberian larutan kitosan dan 4 perlakuan yaitu konsentrasi $0,5 \%$ (A), $1 \%$ (B), 1,5\% (C) dan $2 \%$ (D) serta masing-masing dilakukan tiga kali pengulangan. Perbandingan volume antara larutan kitosan dengan sampel adalah 1:9.

Pembuatan kitosan menurut Sukma et al. (2014) dalam penelitian ini dengan menggunakan cangkang rajungan (Portunus pelagicus) yang telah dipisahkan dari sisa daging yang masih menempel, dicuci bersih dengan air, lalu dikeringkan dibawah sinar matahari \pm 2 hari. Kemudian cangkang dihaluskan dengan menggunakan blender dan diayak menggunakan sieve shaker untuk mendapatkan ukuran butir 50 mesh. Serbuk cangkang rajungan hasil pengayakan ditambahkan $\mathrm{HCl} 2 \mathrm{~N}$ dengan perbandingan 1:4 (b/v) sebagai tahap demineralisasi. Serbuk cangkang diaduk menggunakan magnetic stirrer kecepatan $300 \mathrm{rpm}$ selama 12 jam. Hasil serbuk cangkang lalu didinginkan dan disaring menggunakan kertas saring kasar ukuran 1.620 mesh. Hasil padatan dari penyaringan dicuci dengan aquades hingga $\mathrm{pH}$ netral, lalu dikeringkan pada suhu $100{ }^{\circ} \mathrm{C}$ selama 12 jam dalam oven hingga mencapai berat konstan. Pada tahap deproteinasi, produk demineralisasi ditambahkan larutan $\mathrm{NaOH} 4 \%$ dengan perbandingan 1:10 (b/v), diaduk dengan menggunakan magnetic stirrer sambil dipanaskan pada suhu $100{ }^{\circ} \mathrm{C}$ selama 1 jam, kemudian didinginkan dan disaring menggunakan kertas saring kasar ukuran 1.620 mesh. Endapan dicuci dengan aquades hingga $\mathrm{pH}$ netral, lalu dikeringkan di dalam oven pada suhu $100^{\circ} \mathrm{C}$ hingga mencapai berat konstan. Endapan kitin dari proses deproteinasi dilarutkan dengan $\mathrm{NaOH} 70 \%$ dengan perbandingan 1:20 (b/v) dan di aduk menggunakan magnetic stirrer dengan suhu $100^{\circ} \mathrm{C}$ selama 6 jam, lalu didinginkan pada suhu kamar dan disaring menggunakan kertas saring kasar ukuran 1.620 mesh. Hasil yang sudah disaring lalu dicuci dengan aquades hingga $\mathrm{pH}$ netral, lalu dikeringkan dalam oven pada suhu $100^{\circ} \mathrm{C}$ hingga berat konstan, 
kemudian didinginkan pada suhu kamar dan ditimbang berat akhirnya. Hasil yang didapat berupa kitosan yang akan digunakan untuk uji dengan logam $\mathrm{Pb}$. Kitosan yang dihasilkan tersebut juga diuji FTIR untuk menentukan nilai derajat deasetilasinya.

Sampel air yang digunakan untuk uji memiliki kandungan $\mathrm{Pb}$ sebesar 2,603 mg/L. Pembuatan larutan kitosan dengan melarutkan kitosan (0,5 gram, 1 gram, 1,5 gram dan 2 gram) ke dalam $10 \mathrm{ml}$ asam asetat $1 \%$. Pemberian larutan kitosan 5\%, 10\%, $15 \%$ dan $20 \%$ serta kontrol sebanyak $10 \mathrm{ml}$ (Iriana et al., 2018) untuk penurunan kadar logam berat timbal $(\mathrm{Pb})$ dalam sampel sebanyak $90 \mathrm{ml}$ pada masing-masing konsentrasi sehingga total volume larutan kitosan dengan sampel adalah $100 \mathrm{ml}$. Konsentrasi akhir kitosan adalah $0,5 \%, 1,0 \%, 1,5 \%$, dan 2,0\%. Larutan yang diperoleh selanjutnya dilakukan pengadukan dengan menggunakan magnetic stirrer selama 60 menit dengan kecepatan pengadukan $300 \mathrm{rpm}$ (Nucifera et al., 2016) yang dilakukan pada sampel. Larutan tersebut selanjutnya didiamkan selama 15 menit. Filtrat yang dihasilkan pada saat uji perlakuan kemudian diambil dan dilakukan uji kandungan logam berat dengan menggunakan metode Atomic Absorption Spectrophotometry (AAS). Perhitungan kapasitas adsorpsi kitosan menurut Iriana et al., (2018) adalah sebagai berikut :

$$
\mathrm{qe}=\frac{(\mathrm{Co}-\mathrm{Ce}) \mathrm{V}}{\mathrm{m}}
$$

Keterangan : qe $=$ Kapasitas adsorpsi $(\mathrm{mg} / \mathrm{g}) ; \mathrm{Co}=$ Konsentrasi awal logam timbal $(\mathrm{Pb})(\mathrm{mg} / \mathrm{L}) ; \mathrm{Ce}=$ Konsentrasi akhir logam timbal $(\mathrm{Pb})(\mathrm{mg} / \mathrm{L}) ; \mathrm{V}=$ Volume total (L); $\mathrm{m}=$ Massa adsorben yang digunakan $(g)$

Perhitungan daya adsorpsi kitosan terhadap logam berat timbal $(\mathrm{Pb})$ menurut Iriana et al., (2018) dihitung dengan rumus sebagai berikut:

$$
\text { Daya Adsorpsi }=\frac{[\mathrm{Pb} \text { awal }-\mathrm{Pb} \text { akhir }]}{[\mathrm{Pb} \text { awal }]} \times 100 \%
$$

Data hasil penelitian diolah dengan menggunakan software SPSS. Data sebelumnya dianalisis normalitas dan homogenitasnya, selanjutnya dilakukan uji Anova dua arah dengan selang kepercayaan $95 \%$. Uji Anova digunakan untuk mengetahui perbedaan antar perlakuan, jika terdapat perbedaan antar perlakuan, selanjutnya dilakukan uji lanjut dengan uji BNT untuk mengetahui perlakuan manakah yang memberikan perbedaan (Utami et al., 2014). Jika terdapat interaksi antar variable perlakuan dengan kandungan logam $\mathrm{Pb}$, maka dilanjutkan dengan uji Tukey.

\section{HASIL DAN PEMBAHASAN}

\section{Kapasitas Adsorpsi Kitosan terhadap Logam $\mathbf{P b}$}

Hasil kapasitas adsorpsi kitosan terhadap logam $\mathrm{Pb}$ menunjukkan bahwa perlakuan terbaik dicapai oleh kandungan $0,5 \%$ pada kitosan produk sendiri dengan kisaran $0,093-0,301 \mathrm{mg} / \mathrm{g}$ dengan rata - rata $0,180 \pm 0,015 \mathrm{mg} / \mathrm{g}$, dan kandungan 0,5 $\%$ pada kitosan komersial dengan kisaran 0,076 $0,325 \mathrm{mg} / \mathrm{g}$ dengan rata - rata $0,191 \pm 0,015 \mathrm{mg} / \mathrm{g}$ (Gambar 1). Hasil tersebut menggambarkan bahwa semakin tinggi konsentrasi kitosan yang digunakan maka kapasitas adsorpsinya semakin turun. Hal ini disebabkan karena faktor kekentalan pada konsentrasi kitosan, semakin besar konsentrasinya maka semakin kental larutan kitosan. Kekentalan kitosan menyebabkan proses adsorpsi logam berat timbal pada kitosan tidak berlangsung efektif saat pengadukan dan menyebabkan kemampuan adsorpsinya menurun. Kitosan komersial memiliki viskositas sebesar $50 \mathrm{cPs}$ sehingga lebih efektif pada proses adorpsi, sedangkan kitosan produk sendiri memiliki viskositas 540,57 cPs sehingga proses adsorpsi kurang maksimal karena larutan kitosan terlalu kental. Menurut Iriana et al. (2018) viskositas kitosan yang tinggi menyebabkan proses adsorpsi logam berat timbal pada kitosan tidak berlangsung efektif saat pengadukan dan menyebabkan kemampuan adsorpsinya menurun. Faktor lainnya adalah karena adanya gugus aktif kitosan dalam mengadorpsi logam berat timbal $(\mathrm{Pb})$ telah maksimal. Kitosan mampu menjerap logam berat timbal $(\mathrm{Pb})$ karena bersifat polikationik. Keberadaan gugus hidroksil dan amina sepanjang rantai polimer mengakibatkan kitosan sangat efektif mengadsorpsi kation ion logam berat timbal. Gugus amina berperan sebagai kation yang mampu berikatan dengan logam berat timbal (Pb). Menurut Wulandari (2014), semakin besar konsentrasi kitosan pada $\mathrm{pH}$ dan waktu yang konstan, maka kadar logam timbal $(\mathrm{Pb})$ yang teradsorpsi akan semakin kecil. Hal ini dikarenakan penyebaran adsorbat (logam timbal) meningkat dan waktu yang dibutuhkan untuk mencapai kesetimbangan menjadi lebih lama, sehingga kapasitas adsorpsinya semakin kecil. 
Kapasitas adsorpsi yang semakin berkurang juga dipengaruhi oleh $\mathrm{pH}$ yang terlalu asam. Penelitian ini menggunakan sampel air laut tercemar minyak bumi, sehingga untuk mengawetkan kandungan logam berat timbal $(\mathrm{Pb})$ didalamnya ditambahkan larutan $\mathrm{HNO}_{3}$ hingga $\mathrm{pH}$ nya mencapai $\leq 2(\mathrm{BSN}$, 2004), sebab sifat asam diperlukan agar larutan sampel $\mathrm{Pb}$ (II) membentuk ion dalam larutannya dan tidak ada yang mengendap, sehingga dapat terukur sempurna dengan AAS. Pada $\mathrm{pH}$ yang sangat asam, jumlah ion hidrogen $\left(\mathrm{H}^{+}\right)$sangat banyak sehingga terjadi kompetisi antara ion logam dengan ion hidrogen untuk menempati sisi aktif $\left(\mathrm{NH}_{2}\right)$. Kompetisi ini mengakibatkan terganggunya proses pertukaran ion dan adsorpsi terhadap ion logam Pb. Menurut Asni et al. (2014), $\mathrm{pH}$ optimum untuk kitosan menjadi adsorben adalah dengan menggunakan $\mathrm{pH}$ larutan sebesar 4,5 . Nilai kapasitas adsorpsi yang diperoleh dalam mengadsorpsi ion logam $\mathrm{Pb}$ (II) relatif tinggi pada kondisi yang optimum, pada kondisi ini konsentrasi ion $\mathrm{H}^{+}$berkurang sehingga persaingan antara spesies ion logam dengan ion $\mathrm{H}^{+}$dalam berinteraksi dengan gugus aktif adsorben akan berkurang.

\section{Daya Adsorpsi Kitosan terhadap Logam Pb}

Hasil daya adsorpsi kitosan terhadap logam $\mathrm{Pb}$ menunjukkan bahwa perlakuan terbaik dicapai oleh kandungan 1,5\% pada kitosan produk sendiri

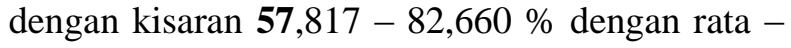

rata $70,547 \pm 6,228 \%$, dan kandungan $1 \%$ pada kitosan komersial dengan kisaran 58,597 - 87,870 $\%$ dengan rata - rata 71,472 $\pm 6,105 \%$ (Gambar 2). Hasil daya adsorpsi pada variabel kontrol positif

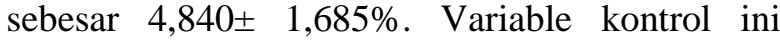
didapatkan dari penambahan asam asetat $1 \%$ sebanyak $10 \mathrm{ml}$ pada sampel tanpa penambahan kitosan. Hasil yang diperoleh pada variable kontrol terjadi penyerapan logam $\mathrm{Pb}$, hal ini disebabkan karena asam asetat memiliki kemampuan mengikat logam (chelating agent) (Maulana et al., 2017). Grafik menunjukkan bahwa semakin banyak konsentrasi kitosan komersial yang digunakan maka persentase adsorpsi akan semakin menurun, berbeda dengan kitosan produk sendiri (kitosan non-komersial) bahwa semakin banyak konsentrasi kitosan yang digunakan maka persentase adsorpsi terhadap logam $\mathrm{Pb}$ akan semakin meningkat hingga konsentrasi $1,5 \%$ selanjutnya mengalami penurunan pada konsentrasi $2 \%$. Daya adsorpsi tertinggi pada penggunaan kitosan komersial sebesar $87,870 \%$ pada konsentrasi $1 \%$, sedangkan daya adsorpsi tertinggi pada penggunaan kitosan produk sendiri (kitosan non-komersial) sebesar $82,660 \%$ pada konsentrasi $1,5 \%$. Penambahan konsentrasi kitosan akan mempengaruhi daya adsorpsi logam berat $\mathrm{Pb}(\mathrm{p}=0,00)$, sedangkan sumber kitosan tidak mempengaruhi daya adsorpsi $(\mathrm{p}=0,722)$. Hal ini dikarenakan pada penggunaan kitosan komersial $1 \%$ telah mampu menyediakan luas permukaan yang cukup untuk terjadinya

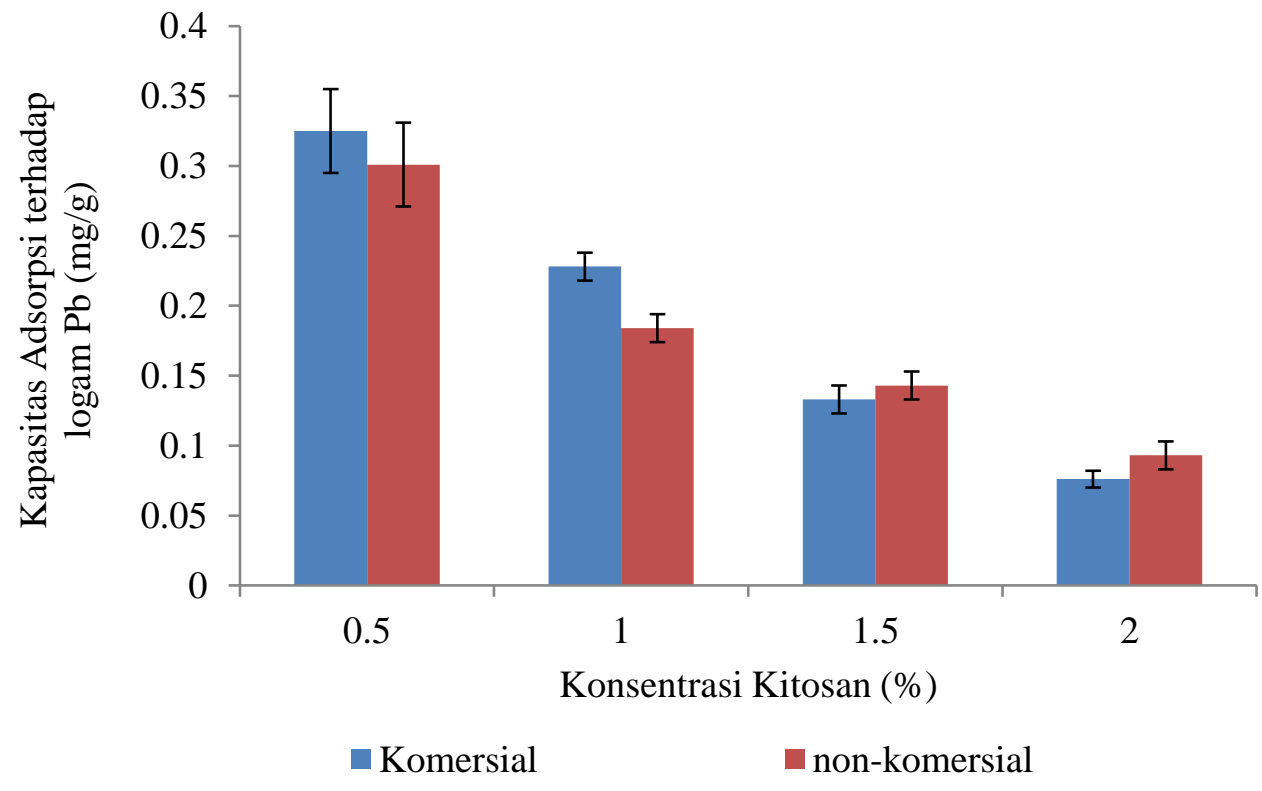

Gambar 1. Grafik Kapasitas Adsorpsi Logam Pb oleh Kitosan 


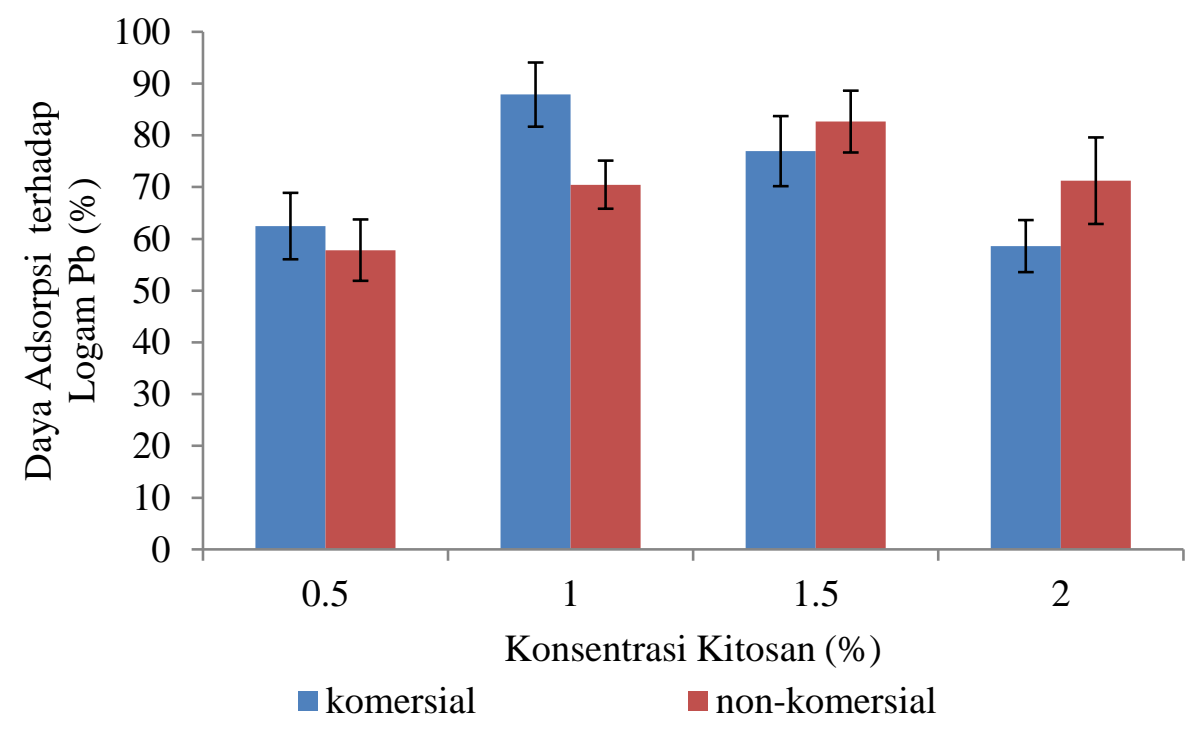

Gambar 2. Grafik Daya Adsorpsi Logam Pb oleh Kitosan

interaksi antara adsorben dengan adsorbat, selain itu juga disebabkan oleh ketersediaan gugus aktif kitosan dalam mengadsorpsi logam berat timbal $(\mathrm{Pb})$ telah maksimal. Hal tersebut juga terjadi pada kitosan produk sendiri (kitosan non-komersial), pada penggunaan konsentrasi $1,5 \%$ gugus aktif kitosan dalam mengadsorpsi logam berat timbal sudah maksimal sehingga pada penggunaan konsentrasi 2\% mengalami penurunan. Penurunan daya adsorpsi ini dapat terjadi karena ikatan yang melemah antara sisi aktif dengan ion logam $\mathrm{Pb}$ (II) sehingga membuat mudah terlepasnya ikatan yang terjadi antara sisi aktif dengan ion logam $\mathrm{Pb}$ (II). Kemampuan kitosan untuk menjerap logam berat akan menurun atau suatu saat dapat konstan, sehingga meskipun massa adsorbennya bertambah banyak tidak akan mempengaruhi adsorpsinya lagi (Iriana et al., 2018). Proses adsorpsi logam $\mathrm{Pb}$ oleh kitosan terjadi seperti pada logam berat lainnya yaitu hanya pada gugus amida $\left(-\mathrm{NH}_{2}\right)$ pada permukaan, maka jumlah logam berat terjerap akan berhenti pada konsentrasi tertentu karena telah mengalami kejenuhan atau terjadi desorpsi (Asni et al., 2014). Mekanisme terjadinya pengikatan ion logam timbal oleh kitosan disebabkan oleh situs aktif yaitu gugus amina dan gugus hidroksil pada rantai polimer kitosan, sehingga mampu menjerap kation ion logam berat (Supriyantini et al., 2018). Interaksi antara ion logam dengan kitosan terjadi melalui pembentukan chelate atau ikatan koordinasi oleh atom $\mathrm{N}$ gugus $\mathrm{NH}_{2}$ dan atom $\mathrm{O}$ gugus $\mathrm{OH}$. Situs aktif pada permukaan kitosan ini disebut sebagai ligan pengikat logam secara selektif.

\section{KESIMPULAN}

Penelitian ini dapat disimpulkan bahwa kitosan dapat menurunkan kadar logam $\mathrm{Pb}$ dalam perairan yang tercemar limbah minyak bumi. Dosis terbaik yang mampu menurunkan logam $\mathrm{Pb}$ untuk kitosan komersial yaitu pada konsentrasi $1 \%$ dengan kapasitas penyerapan sebesar $0,228 \mathrm{mg} / \mathrm{g}$ dan kemampuan penyerapan sebesar $87,870 \%$. Sedangkan kitosan non-komersial mampu menurunkan logam $\mathrm{Pb}$ pada konsentrasi 1,5\% dengan kapasitas penyerapan sebesar $0,143 \mathrm{mg} / \mathrm{g}$ dan kemampuan penyerapan $82,660 \%$.

\section{DAFTAR PUSTAKA}

Asni, N., Saadilah, M.A. \& Saleh, D. 2014. Optimalisasi Sintesis Kitosan dari Cangkang Kepiting sebagai Adsorben Logam Berat $\mathrm{Pb}$ (II). Jurnal Fisika dan Aplikasinya, 15(1):1825.

BSN. 2004. SNI 06-6992.3-2004 Tentang Cara Uji Timbal $(\mathrm{Pb})$ Secara Destruksi Asam dengan Spektrofotometer Serapan Atom (SSA). Jakarta. 13pp

Hananingtyas, I. 2017. Studi Pencemaran Kandungan Logam Berat Timbal $(\mathrm{Pb})$ dan Kadmium (Cd) pada Ikan Tongkol (Euthynnus sp.) di Pantai Utara Jawa. 
Biotropic : The Journal of Tropical Biology, 1(2):41-50.

Iriana, D.D., Sedjati, S. \& Yulianto, B. 2018. Kemampuan Adsorpsi Kitosan dari Cangkang Udang terhadap Logam Timbal. Journal of Marine Research, 7(4):303-309.

Maulana, Umroh \& Kurniawan. 2017. Efektivitas Larutan Asam Cuka dan Jeruk Kunci untuk Menurunkan Kandungan Logam Berat $\mathrm{Pb}$ (Timbal) dalam Daging Kerang Darah (Anadara granosa). Jurnal Sumberdaya Perairan, 11 1):12-18.

Nucifera, I.F., Zaharah, T.A. \& Syahbanu, I. 2016. Uji Stabilitas Kitosan-Kaolin sebagai Adsorben Logam Berat $\mathrm{Cu}$ (II) dalam Air. Jurnal Kimia Khatulistiwa, 5(2):43-49.

Pratiwi, R. 2014. Manfaat Kitin dan Kitosan Bagi Kehidupan Manusia. Oseana, 39(1) : 35-43.

Raja, P.M., \& Nurfajriani. 2017. Pembuatan Adsorben dari Kitosan Cangkang Belangkas (Tachypleus gigas) dan Gelatin untuk Menurunkan Kadar Logam Timbal $(\mathrm{Pb})$. Jurnal Pendidikan Kimia, 9(1):282-285.

Sukma, S., Lusiana, S.E., Masruri \& Suratmo. 2014. Kitosan dari Rajungan Lokal Portunus pelagicus Asal Probolinggo, Indonesia. Jurnal Ilmu Kimia, 2(2):506-512.

Sukma, D.H., Riani, E. \& Pakpahan, E.N. 2018. Pemanfaatan Kitosan sebagai Adsorben Sianida pada Limbah Pengolahan Bijih Emas. Jurnal pengolahan dan hasil perikanan Indonesia, 21(3) : 460-469.
Supriyantini, E., Yulianto, B., Ridlo, A., Sedjati, S. \& Nainggolan, A.C. 2018. Pemanfaatan Chitosan dari Limbah Cangkang Rajungan (Portunus pelagicus) sebagai Adsorben Logam Timbal (Pb). Jurnal Kelautan Tropis, 21(1):23-28.

Susanti, M.M. \& Kristiani, M. 2016. Analisis Kandungan Logam Berat Timbal $(\mathrm{Pb})$ dalam Kerang (Anadara sp.) yang Beredar di Kota Semarang. Indonesian Journal On Medical Science, 3(1):29-34.

Susilowati, E., Mahatmanti, F.W. \& Haryani, S. 2018. Sintesis Kitosan-Silika Bead sebagai Pengadsorpsi Ion Logam $\mathrm{Pb}$ (II) pada Limbah Cair Batik. Indonesian Journal of Chemical Science, 7(2):123-131.

Utami, R.T., Sunaryo \& Sedjati, S. 2014. Studi Penggunaan Kitosan terhadap Penurunan Kadar Amoniak pada Limbah Cair Kilang Minyak Outlet Impounding Basin (OIB) Pertamina RU VI Balongan, Indramayu. Jounal of Marine Research, 3(1):20-26.

Wulandari, Y., Kurniasari, L. \& Riwayati, I. 2014. Adsorpsi Logam Timbal dalam Larutan Menggunakan Kulit Ketela Rambat (Ipomoea batatas L). Prosiding Seminar Nasional Sains Dan Teknologi, 13(5):5-80.

Zaini, H. \& Sami, M. 2017. Penyisihan Pb (II) dalam Air Limbah Laboratorium Kimia Sistem Kolom dengan Bioadsorben Kulit Kacang Tanah. Jurnal Penelitian dan Pengabdian Masyarakat, 5(1):8-14. 